\title{
Market-driven vs. government-driven banking consolidation around the world
}

\author{
Basir Ahmad Mohamadi
}

Senior Communication Officer for office of the Chief Executive Office of the Islamic Republic of Afghanistan Serhii Bohma

Ph.D., Audit \& Assurance / Financial Services, Deloitte \& Touche USC, Ukraine

\begin{abstract}
Today's processes of globalization, deregulation and development of information technologies in the banking sector of countries around the world lead to increase of bank mergers and acquisitions, thus reducing the total amount of banks in the banking system. At the same time, countries, where financial markets are still developing the banking consolidation is led by regulative authorities with strict directions and plans of reduction of banks' quantity in the banking sector. Thus, the objective of this study is to investigate the differences between banking consolidation driven by the market forces and banking consolidation initiated by regulatory authorities. The research occupies the main theoretical basis of both types of banking consolidation and today's overview of the most striking examples of banking consolidation driven by market / government around the world.
\end{abstract}

Keywords: banking consolidation, mergers and acquisitions, banking concentration.

JEL Classification: G28, G34, L51.

DOI: $10.21272 /$ fmir.1(2).96-99.2017.

(C) The Authors, 2017. This article is published with open access at ARMG Publishing.

\section{Introduction}

Banking consolidation is performed due to the wide range of incentives and motives by its participants. Thus, banks taking part in mergers and acquisitions with other banks try to reach the higher level of efficiency (economy on scale, economy on scope), achieve technological progress, increase market share, expand performance in other regions of the world, obtain tax advantages, diversify business, achieve total growth of business, etc. The determination of motives to consolidate is always up to stakeholders of this process. Though, banking consolation arises as a result of market conditions, there is always the presence of some incentives from regulatory authorities to activate mergers and acquisitions as the main forms of consolidation between banks. Meanwhile, regulatory authorities can observe planned bank mergers and acquisitions as the only way to save weak banks and strengthen the banking system of the country by creating large financial institutions which can compete with other participants on international financial markets.

As a result two definitions of banking consolidation around the globe regardless to the main motives of this process have arisen - market-driven and government-driven. It should be noted, that these definitions were actively used by researches when analyzing and investigating consolidation processes which took place in the world in 1990s. During that period a lot of countries suffered from crises and unstable economic conditions in the biggest regions of the world. That's why banking consolidation was mainly initiated and leaded by governments to strengthen financial position of the banking system and lower negative results of crises. Along with this market-driven banking consolidation was a new phenomenon and was significantly observed only in European region.

As nowadays economic conditions are changing together with development of new directions of banking business and softening the regulatory requirements, in this study we will investigate the current state between market-driven and government-driven banking consolidation around the world. Specifically, we will examine current state of banking systems regardless to mergers and acquisitions, which previously experienced the impact of government authorities to compulsory merge and now are adopting new approaches, in particular based on market forces. 


\section{Literature review}

As we have already noticed earlier the definitions of market-driven and government-driven consolidation of banks were used by scientists describing consolidation processes in banking systems around the globe in 1990s. Thus, the paper of R. G. Gelos and J. Roldós (2002) examines the evolution of market structure in emerging markets during the 1990's providing a lot of attention to connection between banking consolidation, concentration and competition. It should be noted that a lot of studies are devoted to the investigation of banking consolidation in emerging markets. Berger, Demsetz, and Strahan (1999) noted that consolidation has been predominant way of resolving problems of financial distress, along with the authorities playing a major role in this process.

The detailed investigation of the banking industry's parameters in the emerging market economies such as competition, consolidation and systemic stability was performed by J. Hawkins and D. Mihaljek (2001) who thoroughly studied the experience of market-driven and government-driven consolidation of banks in different regions of the world.

Among already mentioned studies and researchers we should also take into consideration the following scientists who investigated issues of regulation of consolidation processes in countries' banking systems: J. Barth (2006), J. Jayaratne (1998), Y. Amihud (2002), M. V. Remo (2012), J. Hagendorff (2007) et al.

\section{The main findings of the study}

In any market, consolidation always carried different goals which had been determined by its participants. To distinguish terms of market-driven and government-driven consolidation the first and the main point is what is the main force / motive for it - regulatory impact by the government authority, which usually tries to reach national economic goals within the country (strengthening banking system, protection of depositors, eliminating weak financial institutions, provide conditions to stable and effective money turnover between economic subjects, et al.) or impact by the market (increasing competition between financial institutions, need to increase financial growth and performance to open international markets, open access to financial markets in other countries, development of financial markets, its technologies and financial instruments, et al.).

The next important point is the result of government-driven or market-driven consolidation in the banking system. Usually the government initiates bank mergers and acquisitions during financial crises or restructuring of banking system. In the present case the state supposes that larger financial institutions will be able to lighter withstand financial crises and market fluctuations. Another important case that mergers and acquisitions initiated by government won't be always attractive for acquirers, because during financial restructuring of the banking system large and financially stable banks were obliged to merge with weak banks to safe them. At the same time we can't deny that in case of market-driven consolidation bank-acquires won't buy weak banks. They will do, but very often the propositions and directions of state to acquire some bank are not of that interest for bank-acquires in normal market conditions.

And the third important point that is mostly attributable to peculiarities of market-driven consolidation is a scope of consolidation. The government-driven consolidation is usually limited by authorities and allows mergers and acquisitions of mostly domestic banks, guided mergers and acquisitions with foreign banks were observed at the early stages of foreign bank entry liberalization and is actively applicable in some countries around the world. Accordingly, market-driven consolidation of banks goes far more than regulator-driven as it can lead to transnational mergers and acquisitions resulting in creation of large financial institutions of the world importance. It should be noted that the issue of foreign bank entry is closely connected with banking consolidation among the world and relates to both types of banking consolidation, which are investigated in this study.

There are also other differences between these types of banking consolidation. To provide more detailed features of both types of consolidation we will analyze the experience of different countries around the world.

It should be noted that the large part of countries in Asia and Latin America have great experience of government-driven consolidation. The use of this type of consolidation is explained by the necessity to support and restructure the banking systems as a result of series of financial crises in 1990s.

Thus, the Malaysian government tried to induce the banking consolidation since the early 1990s but no great success had been reached. However, in 1999 the government made an announcement that 54 commercial and 
merchant banks and finance companies would be consolidated into groups, each associated with "anchor" banks. As of 2016 the banking sector of Malaysia remains highly consolidated, with eight domestic players competing in a relatively mature market, comparing to 77 players that existed before the 1997-1998 Asian financial crisis. However, next year can mark up a period of banking consolidation regardless to new Basel III requirements on capital and liquidity.

The consolidation of banking sector in South Korea was performed mainly by state authorities. In the end of 1990s governmental bodies made huge financial inflows to commercial banks. Thus, during the restructuring and consolidation phase the amount of banks decreased from 27 to 17 banks as of 1999. In the 2000s the access to foreign banks in South Korean banking sector was granted. For, example in 2004 the City Group entered the banking sector of South Korea thus representing softening of regulatory requirements and slow crossing to market-driven consolidation processes in the banking system.

Comparing to Korea and Malaysia, Thailand and the Philippines banking consolidation was slower and was performed more with the help of market forces.

For banks acquiring other banks the government of Philippines provided different incentives such as softening prudential requirements, higher rates on discounting bills of exchange, et. al.). Consequently, the government didn't use very strict measures to banks and tried to activate mergers and acquisitions between banks with the help of market forces. The result was positive and led to 11 deals made between banks in 1990s. Today the government stimulates with different "soft" incentives the acquisition of weak rural banks.

Thailand is described with even more soft regulation of banking consolidation in the country. And during the financial crisis in 1990s the government took part only in one deal of mergers and acquisitions between banks.

The banking consolidation was more advanced in Latin America countries, especially in Brazil and Argentina. The crisis in 1990s occurred in this region earlier thus leading to more active inclusion of government in the issues of financial system. It should be noted that during 1990s the amount of banks reduced in all major countries of Latin America. The central banks of Argentina and Brazil were the most successful in reducing the amount of banks. In particular, they used the mechanism of separating troubled banks into good and bad banks and then selling the former with the aid of subsidized loans. After the huge decrease in the amount of banks in these countries, banking consolidation was influenced mainly by the market-driven transactions.

At the beginning of 2014 the Central Bank of Sri Lanka announced the plan of banking sector consolidation to increaser financial stability and competitiveness of banks in the country. To accomplish this the acquiring banks have been granted with tax incentives. During that period the government of Sri Lanka had the goal to exclude banks with total assets less than $100 \mathrm{bln}$. rupees with the help of mergers and acquisitions. The final goal of the state was to create 5 large banks in the country so they can provide financial services not only inside the domestic economy but open international markets and compete with banks - world leaders.

But today's situation provides other prospect on banking consolidation in further years. After presidential elections early in 2015, government pressure for banks to consolidate was replaced by market approach. Meanwhile, officials from the Central Bank of Sri Lanka noted that consolidation would be carried out more systemically and would be a part of new long-term economic policy. Here we can see that there is a sharp crossing from government-driven to market-driven consolidation of banks. However, a lot of representatives from financial services industry agree that the consolidation is needed. At the same time they suppose that the banking sector will be better served if market forces dictate this process. In particular, the change of regulatordriven to market-driven consolidation of banks will help to eliminate accumulation of weak assets in those banks which are forced to merge. We may conclude that this is a positive trend in development of the banking sector of Sri Lanka, but there are also supporters of guided banking consolidation by the state. This is specifically urgent for participants whose interests are not being protected by the market.

The market-driven consolidation is relatively new type of banking consolidation for the last twenty years. For the first time it has arisen in Central Europe where all the necessary conditions for bank mergers and acquisitions under market forces were present. Thus, there was relatively large amount of private banks in the European region and liberalized licensing rules. As a result of high competition between banks, their desire to reduce cost and increase size the consolidation under "market forces" has started. There were no tough government restrictions or obligations to merge which encouraged mergers and acquisitions.

Today European central bankers and supervisors have recently called for greater consolidation of the banking system, in particular in the Eurozone. The main obstacle here is regulation. As banks become larger through 
consolidation they become subject to increasingly tight regulatory hurdles, in particular capital and liquidity requirements. That's why in the near future market-driven consolidation in Europe will be combined with some regulatory instructions. Meanwhile, experts note that in the near future we won't observe such great waves of bank mergers and acquisitions in Europe as in 1990s and 2000s.

\section{Conclusions}

We may conclude that today both market-driven and government-driven consolidation take place in different countries around the world. Though, we may observe gradual movement from regulatory forces used to activate consolidation to market-driven bank mergers and acquisitions, the participation of regulatory authorities on some stages of this process is necessary. It is specifically essential for developing countries where financial markets need more strict regulation and presence of supervisory bodies in all their sectors. At the same time, over concentrated banking systems with large banks around the world are under control of regulatory authorities which in any case will accompany their market-driven mergers and acquisitions with other banks.

\section{References}

1. Jayaratne, J., Strahan, P.E. (1998). Entry Restrictions, Industry Evolution, and Dynamic Efficiency: Evidence from Commercial Banking. Journal of Law and Economics, 41, 239-274.

2. Amihud, Y., DeLong, G.L., Saunders, A. (2002). The Effects of Cross-Border Bank Mergers on Bank Risk and Value. Journal of International Money and Finance, 21, 857-877.

3. Barth, J., Caprio, G., Levine, R. (2006). Rethinking Bank Supervision and Regulation: Until Angels Govern. Cambridge University Press, Cambridge, UK, 438 p.

4. Hagendorff, J., Collins, M., Keasey, K. (2007). Bank Deregulation and Acquisition Activity: The Cases of the US, Italy and Germany. Journal of Financial Regulation and Compliance, 15(2), 199-209.

5. Hosono, K. Sakai, K., Tsuru, K. (2009). Consolidation of Banks in Japan: Causes and Consequences. Financial Sector Development in the Pacific Rim, East Asia Seminar on Economics. 18, 265-309.

6. Hawkins, J., Mihaljek, D. (2001). The banking industry in the emerging market economies: competition, consolidation and systemic stability: an overview. BIS Papers chapters, in: Bank for International Settlements (ed.), The banking industry in the emerging market economies: competition, consolidation and systemic stability, volume 4, pages 1-44 Bank for International Settlements.

7. Berger, Allen N., Rebecca S. Demsetz, and Philip E. Strahan (1999). The Consolidation of the Financial Services Industry: Causes, Consequences, and Implications for the Future. Journal of Banking and Finance, 23 (February), 135-94.

8. International Monetary Fund (2001). International Capital Markets - Developments, Prospects, and Key Policy Issues, Washington, D.C.

9. Gelos, R. G., Roldós, J. (2004). Consolidation and Market Structure in Emerging Markets Banking Systems. Emerging Markets Review, 5. 39-59.

10. Claessens, Stijn, Simeon Djankov, and Larry H.P. Lang (1999). Who Controls East Asian Corporations? Policy Research Working Paper, No. 2054 (Washington: World Bank).

11. Wozniak, L. (2012). Asian M\&A: Still Going Strong, Finance Asia Oct., p. 40-45. 